\title{
Pengaruh Penggunaan Model Pembelajaran Gadget Terhadap Peningkatan Hasil Belajar Matakuliah Zoologi Vertebrata Pada Mahasiswa Program Studi Pendidikan Biologi FKIP Universitas Pattimura
}

\author{
Hasan Tuaputty ${ }^{1}$ Tri Santi Kurnia $^{1}$ Rufiati Simal $^{1}$ Rivaldo Malawat $^{2}$ \\ ${ }^{1}$ Dosen Program Studi Pendidikan Biologi FKIP Universitas Pattimura \\ ${ }^{2}$ Alumni Program Studi Pendidikan Biologi FKIP Universitas Pattimura \\ E-mail: hasantuaputty@gmal.com
}

\begin{abstract}
Abstrak: Pemikiran paradigma pendidikan pada abad ke 21 yang selaras dengan perkembangan ilmu pengetahuan teknologi. Diakui sekarang ini bahwa program komputasi seluler memungkinkan Dosen merekam data assessmen mahasiswa secara langsung dalam perangkat seluler (mobile Device). Selain itu, perangkat elektronik dapat dioperasionalkan untuk meningkatkan kemampuan mahasiswa belajar dalam bentuk pendalaman kajian teori, yang berkaitan dengan presentasi, eksperimen kegiatan laboratorium, atau tugas tulisan mahasiswa. Selanjutnya mobile device ini dapat disebut gadget. Tujuan dari penelitian ini adalah untuk mengetahui pengaruh penggunaan model pembelajaran gadget terhadap hasil belajar dan kecerdasan berfikir dalam menyelesaikan tugas matakuliah zoologi vertebrata pada mahasiswa program studi pendidikan biologi FKIP Unpatti. Penelitian ini dilaksanakan Fakultas Keguruan dan Ilmu Pendidikan Universitas Pattimura Program Studi Pendidikan Biologi, pada tanggal 10 Ferbuari - 10 Juni 2019. data dianalisis secara statistik inferensial menggunakan aplikasi SPSS 2.0
\end{abstract}

\section{Kata Kunci: Model Pembelajaran Gadget, Kecerdasan Berpikir, Hasil Belajar}

\begin{abstract}
Educational paradigm thoughts in this $21^{\text {st }}$ century in line with the development of science and technology. We see nowadays that cellular computation program enables lecturer to record students`assessment data directly from mobile device. Besides, by the use of electronical devices that could be operated to increase and enhance students` learning in various way like enhancing students` understanding in theories, related with a performance or presentation, lab and experiments or written task and assignments. Then mobile device termed gadget. To know the influence of gadget learning model usage towards students` learning result and thinking skill in accomplishing assignments on vertebrate zoology course of college students from biology education faculty of education pattimura university. This research being held in Faculty of Education Pattimura University Biology Education, on Ferbuary $10^{\text {th }}$ - June $10^{\text {th }} 2019$. Data will be analyzed statistically using SPSS 2.0
\end{abstract}

Key Words: Gadget Learning Model, Thinking Skill, Students`Learning Result 
Pemikiran paradigma pendidikan pada abad ke 21 yang selaras dengan perkembangan ilmu pengetahuan teknologi yang berkembang secara linier sejalan dengan tuntutan masyarakat akademik, dimana kepraktisan teknologi digital bagi pemenuhan hidup masyarakat akademik itu sendiri, yang secara transparan tidak dapat dihindari oleh perkembangan ilmu pengetahuan dan teknologi. Tuntutan kebutuhan ilmu dan teknologi sangat berkembang pada masyarakat akademik yang berorentasi teknologi digital sekarang ini. Saat ini, kegiatan perkuliahan sering dilakukan dalam bentuk community of practice (COP), di mana kelompok dosen dan mahasiswa yang mempunyai tujuan sama dari seluruh proses perkuliahan saling berbagi ide dan konsep yang dipelajari akibat pemanfaatan elektronik digital. Interaksi berbasis Internet ini memungkinkan dosen untuk berkolaborasi dan berinovasi dalam berkomunikasi.

Menurut Winarno (2009), gadget merupakan seperangkat alat elektronik berukuran kecil yang memiliki fungsi khusus dalam berbagai bentuk komunikasi. Ini artinya gadget dapat diistilahkan sebagai alat interaksi antara komunitas manusia, termasuk interaksi antara dosen dan mahasiswa karena secara langsung penggunaan gadget dapat mempengaruhi bentuk pembelajaran. Penggunaan gadget sebagai model pembelajaran dalam perkuliahan yang dihubungkan dengan komputer berbasis internet memudahkan dan mempercepat mahasiswa dalam mencari sumber belajar tanpa terbatas waktu dan tempat. Ponsel pintar (android), tablet, dan laptop yang terhubung dengan saluran internet dapat digunakan untuk sarana interaksi antara mahasiswa dan dosen, terutama mengirim tugastugas yang diberikan dosen.

Pada umumnya interaksi melalui gadget belum sepenuhnya dapat dilakukan oleh mahasiswa dalam proses perkuliahan, akan tetapi mahasiswa yang memiliki kecerdasan berfikir, kecerdasan bertindak melalui pembelajaran dengan model gadget diharapkan dapat meningkatkan hasil belajar. Hal ini sejalan dengan pandangan Harfiyanto, Cahyo dkk (2015), bahwa, siswa (mahasiswa) banyak menggunakan gadget dalam proses pembelajarannya terutama pada saat proses diskusi di dalam kelas. Gadget juga dapat mempermudah mahasiswa dalam mengerjakan tugas-tugas yang diberikan dosen. Selain itu, di dalam gadget juga tersedia situs sosial media seperti email, facebook, twitter dan Instagram yang digunkan mahasiswa.

Kuroyuki (2013) menjelaskan bahwa gadget dapat membantu gaya pembelajaran, misalnya untuk dapat mengakses sebuah situs untuk mencari artikel atau materi-materi yang sedang dikerjakan, bahkan proses perkuliahan yang menggunakan gadget pengaruhnya positif lebih besar jika siswa (mahasiswa) memanfaatkan gadget dengan baik. Melalui proses perkuliahan matakuliah vertebrata dimungkinkan mahasiswa memiliki aspek-aspek yang terkait dengan (1) bertambahnya pemahaman konsep vertebrata, (2) adanya kemampuan mengingat dan memproduksi konsep vertebrata, (3) ada kemampuan aplikasi pengetahuan vertebrata, (4) menyimpulkan makna konsep vertebrata, (5) menafsirkan dan mengaitkannya dengan realitas kehidupan vertebrata. 


\section{METODE PENELITIAN}

Penelitian ini merupakan tipe menelitian deskriptif, yakni mengungkapkan fenomena yang terjadi pada proses perkuliahan dengan model gadget pada mahasiswa yang menawarkan matakuliah vertebrata program studi pendidikan biologi FKIP Unpatti. Penelitian ini dilaksanakan Fakultas Keguruan dan Ilmu Pendidikan Universitas Pattimura Program Studi Pendidikan Biologi, pada tanggal 10 Ferbuari - Juni 10 Tahun 2019. Subjek penelitian adalah mahasiswa yang mengambil matakuliah vertebrata sebanyak 33 orang pada semester genap tahun ajaran 2019.

\section{HASIL DAN PEMBAHASAN}

Berdasarkan data yang terungkap pada penerapan model pembelajaran gadget yang diterapkan dalam perkuliahan matakuliah zoology vertebrata ternyata terlihat adanya keberhasilan mahasiswa dalam menyelesaikan tugas-tugas serta memungkinkan mahasiswa berhasil dalam proses perkuliahan. Penerapan model pembelajaran gadget yang diikuti oleh kemampuan atau ketrampilan menggunakan gaget sangat berpengaruh terhadap kecerdasan berpikir, peningkatan pengetahuan, kecerdasan unjuk kerja (psikomotor), sikap serta hasil belajar terhadap matakuliah zoology vertebrata. Hal ini terlihat dari hasil analisis sesuai rentang skor kriteria pencapaian yang diperoleh, seperti terlihat pada tabel dibawah ini.

Tabel. 1. Hasil Analisis Frekwensi dan Persentase Kriteri Pencapaian Keberhasilan Dari 33 Orang Mahasiswa Melalui Model Pembelajaran Gadget

\begin{tabular}{|c|c|c|c|c|c|c|c|c|c|c|c|c|c|}
\hline \multirow{3}{*}{ Skor } & \multirow{3}{*}{$\begin{array}{l}\text { Kriter } \\
\text { ia }\end{array}$} & \multicolumn{12}{|c|}{ Hasil Penilaian } \\
\hline & & \multicolumn{2}{|c|}{$\begin{array}{l}\text { Ketrampi } \\
\text { lan } \\
\text { Menggun } \\
\text { akan } \\
\text { Gadget }\end{array}$} & \multicolumn{2}{|c|}{$\begin{array}{l}\text { Berpiki } \\
\text { r Kritis }\end{array}$} & \multicolumn{2}{|c|}{$\begin{array}{l}\text { Tugas } \\
\text { Makala } \\
\text { h }\end{array}$} & \multicolumn{2}{|c|}{$\begin{array}{l}\text { Unjuk } \\
\text { Kerja } \\
\text { (psikomoto } \\
\text { r) }\end{array}$} & \multicolumn{2}{|c|}{ Sikap } & \multicolumn{2}{|c|}{ NA } \\
\hline & & $\mathrm{F}$ & $\%$ & $\mathrm{~F}$ & $\%$ & $\mathrm{~F}$ & $\%$ & $\mathrm{~F}$ & $\%$ & $\bar{F}$ & $\%$ & $\mathrm{~F}$ & $\%$ \\
\hline $90-100$ & $\begin{array}{l}\text { Sanga } \\
\text { t Baik }\end{array}$ & 13 & $\begin{array}{l}39,4 \\
\%\end{array}$ & 7 & $\begin{array}{l}21 \\
, 2 \\
\%\end{array}$ & 7 & $\begin{array}{l}21 \\
, 2 \\
\%\end{array}$ & 13 & $\begin{array}{l}39,4 \\
\%\end{array}$ & 13 & $\begin{array}{l}39,4 \\
\%\end{array}$ & 12 & $36,4 \%$ \\
\hline $80-88,9$ & Baik & 9 & $\begin{array}{l}27,3 \\
\%\end{array}$ & 8 & $\begin{array}{l}24 \\
, 2 \\
\%\end{array}$ & 15 & $\begin{array}{l}45 \\
, 5 \\
\%\end{array}$ & 10 & $\begin{array}{l}30,3 \\
\%\end{array}$ & 4 & $\begin{array}{l}12,1 \\
\%\end{array}$ & 7 & $21,2 \%$ \\
\hline $70-79,9$ & $\begin{array}{l}\text { Cuku } \\
\mathrm{p}\end{array}$ & 11 & $\begin{array}{l}33,3 \\
\%\end{array}$ & 11 & $\begin{array}{l}33 \\
\% \\
\%\end{array}$ & 11 & $\begin{array}{l}33 \\
, 3 \\
\%\end{array}$ & 10 & $\begin{array}{l}30,3 \\
\%\end{array}$ & 11 & $\begin{array}{l}33,3 \\
\%\end{array}$ & 14 & 42,4 \\
\hline $60-69,9$ & $\begin{array}{l}\text { Kura } \\
\text { ng }\end{array}$ & 0 & $0 \%$ & 6 & $\begin{array}{l}18 \\
, 2 \\
\%\end{array}$ & 0 & $\begin{array}{l}0 \\
\%\end{array}$ & 0 & $0 \%$ & 5 & $\begin{array}{l}15,2 \\
\%\end{array}$ & 0 & $0 \%$ \\
\hline $\begin{array}{ll}0 & < \\
59,9 & \end{array}$ & Jelek & 0 & $0 \%$ & 1 & $\begin{array}{l}3, \\
03 \\
\%\end{array}$ & 0 & $\begin{array}{l}0 \\
\%\end{array}$ & 0 & $0 \%$ & 0 & $0 \%$ & 0 & $0 \%$ \\
\hline
\end{tabular}




\begin{tabular}{|l|l|l|l|l|l|l|l|l|l|l|l|l|l|}
\hline $\begin{array}{l}\text { Jumla } \\
\mathrm{h}\end{array}$ & 33 & $\begin{array}{l}100 \\
\%\end{array}$ & 33 & $\begin{array}{l}10 \\
0 \\
\%\end{array}$ & 33 & $\begin{array}{l}10 \\
0 \\
\%\end{array}$ & 33 & $100 \%$ & 33 & $\begin{array}{l}100 \\
\%\end{array}$ & 33 & $100 \%$ \\
\hline
\end{tabular}

Berdasarkan data pada table 1 di atas dapat dijelaskan bahwa penerapan model pembelajaran gadget pada matakuliah zoologi vertebrata yang diikuti oleh 33 orang mahasiswa ternyata diperoleh hasil sebagai berikut:

a). Kemampuan menggunakan gadget dengan keriteria sangat baik 39,4\% atau 13 orang mahasiswa, kriteria baik 27,3\% atau 9 orang mahasiswa, kriteria cukup 33,3\% atau 11 orang mahasiswa.

b). Kemampuan berpikir kritis dengan kriteria sangat baik $21,2 \%$ atau 7 orang, kriteria baik $24,2 \%$ atau 8 orang mahasiswa, kriteria cukup 33,3\% atau 11 orang mahasiswa, kriteria kurang 18,2\% atau 6 orang mahasiswa, dan kriteria jelek 1 orang mahasiswa.

c). Kemampuan menyelesaikan tugas makalah dengan kriteria sangat baik $21,2 \%$ atau 7 orang mahasiswa, kriteria baik $45,5 \%$ atau 15 orang mahasiswa, kriteria cukup 33,3\% atau 11 orang mahasiswa.

d). Kemampuan Unjuk kerja (psikomotor) dengan kriteria sangat baik 39,4\% atau 13 orang, kriteria baik 30,3\% atau 10 orang mahasiswa dan kriteria cukup 30,3\% atau 10 orang mahasiswa.

e).Sikap yang diperlihatkan mahasiswa dengan kriteria sangat baik 39,4\% atau 13 orang mahasiswa, kriteria baik $12,1 \%$ atau 4 orang mahasiswa, kriteria cukup 33,3\% atau 11 orang mahasiswa, kriteria kurang $15,2 \%$ atau 5 orang mahasiswa

f).Hasil belajar atau nilai akhir yang diperoleh melalui penilaian proses belajar model pembelajaran gadget dan hasil tes konsep vertebrata diperoleh kriteria sangat baik $36,4 \%$ atau 12 orang mahasiswa, kriteria baik $21,2 \%$ atau 7 orang mahasiswa, kriteria cukup $42,4 \%$ atau 14 orang mahasiswa.

Berdasarkan permasalahan dan hipotesis yang diajukan, dilakukan statistis inverensial, yaitu uji pengaruh penerapan model pembelajaran gadget (kemampuan menggunakan gadget) terhadap beberapa hal selama proses perkuliahan, antara lain:

1. Pengaruh Penggunaan Gadget Terhadap Berpikir Kritis Selama Proses Perkuliahan. Berdasarkan hasil analisis anova untuk melihat pengaruh ketrampilan menggunkan gadget terhadap kemampuan berpikir kritis selama proses perkuliahan matakuliah zoology vertebrata dengan menggunakan model pembelajaran gadget, maka diperoleh hasil, seperti tertera pada tabel 2, dibawah ini

Tabel 2. Hasil Uji Variance Penerapan Model Pembelajaran Gadget Terhadap Berpikir Kritis Pada Mahasiswa Selama Proses Perkuliahan Matakuliah Zoologi Vertebrata

\begin{tabular}{|c|c|c|c|c|c|c|c|c|}
\hline Source & $\begin{array}{l}\text { Type III } \\
\text { Sum of } \\
\text { Squares }\end{array}$ & Df & $\begin{array}{l}\text { Mean } \\
\text { Square }\end{array}$ & $F$ & Sig. & $\begin{array}{l}\text { Partial } \\
\text { Eta } \\
\text { Square } \\
\text { d }\end{array}$ & \begin{tabular}{|l} 
Non \\
cent. \\
Para \\
mete \\
$\mathrm{r}$
\end{tabular} & $\begin{array}{l}\text { Obser } \\
\text { ved } \\
\text { Power }\end{array}$ \\
\hline
\end{tabular}




\begin{tabular}{|l|l|l|l|l|l|l|l|l|l|}
\hline $\begin{array}{l}\text { Interce } \\
\mathrm{pt}\end{array}$ & $\begin{array}{l}\text { Hypothesi } \\
\mathrm{s}\end{array}$ & $\begin{array}{l}145059.60 \\
3\end{array}$ & 1 & 145059.603 & $\begin{array}{l}783 . \\
947\end{array}$ & .000 & .989 & $\begin{array}{l}783 . \\
947\end{array}$ & 1.000 \\
\cline { 2 - 10 } & Error & 1562.583 & $\begin{array}{l}8.44 \\
5\end{array}$ & $185.037^{\mathrm{a}}$ & & & & & \\
\hline $\begin{array}{l}\text { Berpiki } \\
\text { r.Kritis }\end{array}$ & $\begin{array}{l}\text { Hypothesi } \\
\mathrm{s}\end{array}$ & 2128.636 & 8 & 266.080 & $\begin{array}{l}17.3 \\
37\end{array}$ & .000 & .852 & $\begin{array}{l}138 . \\
698\end{array}$ & 1.000 \\
\cline { 2 - 9 } & & & & & & & & \\
\hline
\end{tabular}

Berdasarkan table 2 di atas dapat dijelaskan bahwa nilai $F_{\text {hitung }}$ sebesar 783,947 dengan signifikansi $\mathrm{F}$ hitung adalah 0,000 dan nilai koefesien 0,990 > nilai Partial squared 0,989. Hal ini berarti hipotesis nol (H0) ditolak, sedangkan hipotesis penelitian diterima, yang menyatakan" ada pengaruh model pembelajaran gadget berpengaruh terhadap berpikir kritis selama proses perkuliahan matakuliah zoologi vertebrata. Hasil analisis pada tabel yang sama di atas juga memberi penjelasan nilai $\mathrm{F}_{\text {hitung }}$ sebesar 17.337 dengan

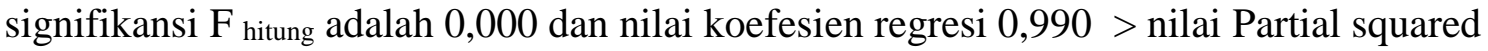
0,852. Hal ini berarti hipotesis nol (H0) ditolak, sedangkan hipotesis penelitian diterima, yang menyatakan" ada pengaruh ketrampilan menggunakan gadget berpengaruh terhadap berpikiri kritis selama proses perkuliahan

2. Analisi Pengaruh Penggunaan Gadget Terhadap Penyelesaian Tugas Makalah

Berdasarkan hasil analisis variance untuk mengetahui pengaruh ketrampilan menggunakan gadget terhadap penyelesaian tugas makalah, diperoleh hasil analisis seperti tertera pada table 3 dibawah ini.

Tabel 3. Pengaruh Penerapan Model Gadget (Ketrampilan Menggunakan Gadge) Terhadap Penyelesaian Tugas Makalah

\begin{tabular}{|c|c|c|c|c|c|c|c|c|}
\hline \multicolumn{9}{|c|}{ Tests of Between-Subjects Effects } \\
\hline \multicolumn{9}{|c|}{ Dependent Variable: GADGET } \\
\hline Source & $\begin{array}{l}\text { Type III } \\
\text { Sum of } \\
\text { Squares }\end{array}$ & df & $\begin{array}{l}\text { Mean } \\
\text { Square }\end{array}$ & $\mathrm{F}$ & Sig. & $\begin{array}{l}\text { Partial Eta } \\
\text { Squared }\end{array}$ & $\begin{array}{l}\text { Noncent. } \\
\text { Parameter }\end{array}$ & $\begin{array}{l}\text { Observed } \\
\text { Power }^{\mathrm{b}}\end{array}$ \\
\hline $\begin{array}{l}\text { Corrected } \\
\text { Model }\end{array}$ & $2351.880^{\mathrm{a}}$ & 6 & 391.980 & 70.243 & .000 & .942 & 421.457 & 1.000 \\
\hline Intercept & $\begin{array}{l}114260.19 \\
1\end{array}$ & 1 & \begin{tabular}{|l}
114260. \\
191
\end{tabular} & $\begin{array}{l}20475 . \\
426\end{array}$ & .000 & .999 & 20475.426 & 1.000 \\
\hline $\begin{array}{l}\text { MAKAL } \\
\text { AH }\end{array}$ & 2351.880 & 6 & 391.980 & 70.243 & .000 & .942 & 421.457 & 1.000 \\
\hline Error & 145.089 & 26 & 5.580 & & & & & \\
\hline Total & $\begin{array}{l}230000.00 \\
0\end{array}$ & 33 & & & & & & \\
\hline $\begin{array}{l}\text { Corrected } \\
\text { Total }\end{array}$ & 2496.970 & 32 & & & & & & \\
\hline \multicolumn{9}{|c|}{ a. R Squared $=.951$ (Adjusted R Squared $=.928)$} \\
\hline & 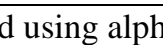 & $1=$ & & & & & & \\
\hline
\end{tabular}


Berdasarkan data pada table 3 di atas dapat kemukakan bahwa nilai $\mathrm{F}_{\text {hitung sebesar }}$ 70,243 dengan signifikansi $\mathrm{F}_{\text {hitung }}$ adalah 0,000 dan nilai koefesien 0,951 > nilai Partial squared 0,942. Hal ini berarti hipotesis nol (H0) ditolak, sedangkan hipotesis penelitian diterima, yang menyatakan" ada pengaruh model pembelajaran gadget terhadap penyelesaian tugas makalah selama proses perkuliahan matakuliah zoologi vertebrata diterima”. Analisis Penggaruh Penggunaan Gadget Terhadap Unjuk Kerja (Psikomotor)

Berdasarkan hasil analisis avariance untuk mengetahui pengaruh kemampuan menggunakan gadget terhadap unjuk kerja (psikomotor), diperoleh hasil analisis seperti tertera pada tabel 4 dibawah ini

Tabel 4. Hasil Analisis Varianve Penerapan Model Pembelajaran Gadget Terhadap Unjuk Kerja (Psikomotor) Pembedahan Hewan Vertebrata Selama Proses Perkuliahan

\begin{tabular}{|l|l|l|l|l|l|l|l|l|}
\hline & $\begin{array}{l}\text { Type III } \\
\text { Sum of } \\
\text { Squares }\end{array}$ & df & $\begin{array}{l}\text { Mean } \\
\text { Square }\end{array}$ & F & Sig. & $\begin{array}{l}\text { Partial Eta } \\
\text { Squared }\end{array}$ & $\begin{array}{l}\text { Noncent. } \\
\text { Parameter }\end{array}$ & $\begin{array}{l}\text { Observe } \\
\text { d Power }\end{array}$ \\
\hline Corrected Model & $2384.261^{\mathrm{a}}$ & 6 & 397.377 & 91.668 & .000 & .955 & 550.011 & 1.000 \\
\hline Intercept & 179612.992 & 1 & $\begin{array}{l}179612.99 \\
2\end{array}$ & 41433.829 & .000 & .999 & 41433.829 & 1.000 \\
\hline Unjuk Kerja & 2384.261 & 6 & 397.377 & 91.668 & .000 & .955 & 550.011 & 1.000 \\
\hline Error & 112.708 & 26 & 4.335 & & & & & \\
\hline Total & 230000.000 & 33 & & & & & & \\
\hline Corrected Total & 2496.970 & 32 & & & & & & \\
\hline
\end{tabular}

a. R Squared $=.962($ Adjusted R Squared $=.944)$

b. Computed using alpha $=.05$

Berdasarkan data analisis variance pada table 4 di atas dapat kemukakan bahwa

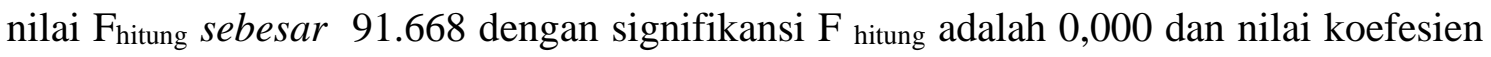
$0,962>$ nilai Partial squared 0,955. Hal ini berarti hipotesis nol (H0) ditolak, sedangkan hipotesis penelitian diterima, yang menyatakan" ada pengaruh model pembelajaran gadget terhadap unjuk kerja (psikomotor) pembedahan hewan vertebrata selama proses perkuliahan matakuliah diterima".

3. Penggaruh Penggunaan Gadget Terhadap Sikap Mahasiswa

Berdasarkan hasil analisis variance untuk mengetahui pengaruh ketrampilan menggunakan gadget terhadap sikap mahasiswa selama proses perkuliahan, diperoleh hasil analisis seperti tertera pada table 5 dibawah ini

Tabel 5. Hasil Analisis Variance Penerapan Model Pembelajaran Terhadap Sikap Mahasiswa Selama Proses Perkuliahan

\begin{tabular}{|l|l|l|l|l|l|l|l|l|}
\hline & $\begin{array}{l}\text { Type III } \\
\text { Sum of } \\
\text { Squares }\end{array}$ & df & $\begin{array}{l}\text { Mean } \\
\text { Square }\end{array}$ & F & Sig. & $\begin{array}{l}\text { Partial } \\
\text { Eta } \\
\text { Squared }\end{array}$ & $\begin{array}{l}\text { Noncent. } \\
\text { Parameter }\end{array}$ & $\begin{array}{l}\text { Observe } \\
\text { d } \\
\text { Power }^{\mathrm{b}}\end{array}$ \\
\hline Corrected Model & $\begin{array}{l}2129.807^{\mathrm{a}} \\
\text { Intercept }\end{array}$ & 7 & 304.258 & 20.717 & .000 & .853 & 145.018 & 1.000 \\
148670.759 & 1 & 148670.759 & 10122.9 & .000 & .998 & 10122.948 & 1.000 \\
SIKAP & 2129.807 & 7 & 304.258 & 20.717 & .000 & .853 & 145.018 & 1.000 \\
Error & 367.163 & 25 & 14.687 & & & &
\end{tabular}

BIOLOGI SEL (VOL 8 NO 2 EDISI JUL-DES 2019 ISSN 2252-858X/E-ISSN 2541-1225) PAGE 176 
$\mid \begin{aligned} & \text { Total } \\ & \text { Corrected Total }\end{aligned}$

\begin{tabular}{|l|l|}
230000.000 & 33 \\
2496.970 & 32 \\
\hline
\end{tabular}

a. R Squared $=.862$ (Adjusted R Squared $=.812)$

b. Computed using alpha $=.05$

Berdasarkan data analisis variance pada table 5 di atas dapat kemukakan bahwa nilai $F_{\text {hitung }}$ sebesar 20.717 dengan signifikansi $F$ hitung adalah 0,000 dan nilai koefesien 0,862 > nilai Partial squared 0,853. Hal ini berarti hipotesis nol (H0) ditolak, sedangkan hipotesis penelitian diterima, yang menyatakan" ada pengaruh model pembelajaran gadget terhadap sikap mahasiswa selama proses perkuliahan diterima"

4. Pengaruh Penggunaan Gadget Terhadap Hasil Belajar

Berdasarkan hasil analisis anova untuk mengetahui pengaruh ketrampilan menggunakan gadget terhadap hasil belajar konsep zoology vertebrata selama proses perkuliahan, diperoleh hasil analisis seperti tertera pada table 6 dibawah ini

Tabel 6. Hasil Analisis Variance Penerapan Model Pembelajaran Gadget Terhadap Hasil Belajar Konsep Vertebrata Selama Proses Perkuliahan

\begin{tabular}{|c|c|c|c|c|c|c|c|c|}
\hline \multicolumn{9}{|c|}{ Tests of Between-Subjects Effects } \\
\hline \multicolumn{9}{|c|}{ Dependent Variable: GADGET } \\
\hline Source & $\begin{array}{l}\text { Type III Sum } \\
\text { of Squares }\end{array}$ & df & Mean Square & $\mathrm{F}$ & Sig. & \begin{tabular}{|l} 
Partial \\
Eta \\
Squared
\end{tabular} & $\begin{array}{l}\text { Noncent. } \\
\text { Parameter }\end{array}$ & $\begin{array}{l}\text { Observed } \\
\text { Power }^{b}\end{array}$ \\
\hline $\begin{array}{l}\text { Corrected } \\
\text { Model }\end{array}$ & $2421.970^{\mathrm{a}}$ & 28 & 86.499 & 4.613 & .073 & .970 & 129.172 & .575 \\
\hline Intercept & 213333.333 & 1 & 213333.333 & 11377.778 & .000 & 1.000 & 11377.778 & 1.000 \\
\hline Nilai Akhir & 2421.970 & 28 & 86.499 & 4.613 & .073 & .970 & 129.172 & .575 \\
\hline Error & 75.000 & 4 & 18.750 & & & & & \\
\hline Total & 230000.000 & 33 & & & & & & \\
\hline $\begin{array}{l}\text { Corrected } \\
\text { Total }\end{array}$ & 2496.970 & 32 & & & & & & \\
\hline \multicolumn{9}{|c|}{ a. $\mathrm{R}$ Squared $=.976($ Adjusted R Squared $=.760)$} \\
\hline b. Compute & sing alpha $=$ & & & & & & & \\
\hline
\end{tabular}

Berdasarkan data analisis variance pada table 6 di atas dapat kemukakan bahwa nilai $F_{\text {hitung }}$ sebesar 4.613 dengan signifikansi $F$ hitung adalah 0,073 dan nilai koefesien 0,976 > nilai Partial squared 0,970. Hal ini berarti hipotesis nol (H0) ditolak, sedangkan hipotesis penelitian diterima, yang menyatakan" ada pengaruh model pembelajaran gadget terhadap hasil belajar konsep vertebrata selama proses perkuliahan diterima"

Melalui model pembelajaran Gadget memudahkan mahasiswa berkomunikasi, serta memperlancar unjuk kerja, memudahkan mahasiswa mengerjakan tugas tugas selama proses perkuliahan berlangsung. Penerapan model pembelajaran gadget dalam proses perkuliahan matakuliah zoology vertebrata senantiasa mengembangkan ketrampilan dan kecerdasan mahasiswa dalam menggunakan gadget yang mereka dimiliki. Penerapan model pembelajaran gadget lebih menekan pada kemampuan mahasiswa menggunakan gadget, sebab sangat membantu mahasiswa dalam berinteraksi baik sesame mereka bahkan interaksi dengan dosen dalam memperoleh informasi 
mengenai proses perkuliahan serta penyelesaian masalah yang dihadapi mahasiswa dalam selama proses perkuliahan berlangsung.

Pembelajaran model gadget merupakan suatu sistem yang dapat memfasilitasi mahasiswa belajar lebih luas, lebih banyak, dan bervariasi. Melalui fasilitas yang disediakan oleh sistem tersebut, pembelajar dapat belajar kapan dan dimana saja tanpa terbatas oleh jarak, ruang dan waktu. Materi pembelajaran yang dipelajari lebih bervariasi, tidak hanya dalam bentuk verbal, melainkan lebih bervariasi seperti teks, visual, audio, dan gambar gerak atau video, bahkan dapat akses melalui internet. Perkembangan teknologi dan komunikasi telah memberikan dampak bagi kehidupan, salah satunya yaitu dengan munculkan gadget.Gadget merupakan teknologi komunikasi yang paling berkembang saat ini, gadget memiliki banyak fungsi selain untuk berkomunikasi, gadget dapat digunakan sebagai sumber belajar dan media hiburan untuk menonton video, mendengarkan musik dan untuk mengabadikan momen melalui kamera.

Pelaksanaan perkuliahan matakuliah zoology vertebrata dilakukan dengan menggunakan model pembelajaran gadget juga mencakup aspek infrastruktur berupa seperangkat komputer yang saling berhubungan satu sama lainnya, selain itu melalui gadget dapat berkomunikasi diantara sesama mahasiswa yang memiliki gadget. Kemampuan menggunakan gadget untuk mengirimkan data, baik berupa teks, pesan, grafis, ganbar maupun video. Hal ini sejalan dengan pandangan Munir (2017) bahwa pembelajaran digital termasuk model pembelajaran gadget, yang bukan hanya berkaitan dengan perangkat keras saja, melainkan juga mencakup perangkat lunak berupa data yang dikirim ke dosen dan bahkan dapat disimpan sewaktu-waktu dapat diakses kembali. Penerapan pembelajaran digital dengan menggunkan beberapa komputer saling berhubungan satu sama lain dapat menciptakan fungsi sharing yang secara sederhana, hal ini dapat disebut sebagai jaringan (networking). Fungsi sharing yang tercipta melalui jaringan (networking) tidak hanya mencakup fasilitas yang sangat dan sering dibutuhkan mahasiswa, dalam proses perkuliahan, tetapi dosen dan mahasiswa juga dapat menggunakan model pembelajaran gadget, terutama yang berkaitan dengan data atau program aplikasi tertentu seperti WA.

Mengingat perkuliahan dengan model gadget sebagai sarana komunikasi mampu memberikan manfaat besar bagi kepentingan dosen dan juga mahasiswa. Olehnya itu mahasiswa perlu memahami karakteristik atau potensi pemanfaatan gadget. Memanfaatkan gadget secara optimal untuk kepentingan kecerdasan berpikir kritis, penyelesaian tugas atau penyusunan makalah sangat penting. Adanya penggaruh model pembelajaran gadget terhadap kecerdasan berpikir kritis mahasiswa selama proses perkuliahan yang berkaitan dengan mengakses materi secara online yang diberikan dosen, terbukti analisis yang menunjukan bahwa ada pengaruh model pembelajaran gadget dengan nilai koefesien 0,990> nilai partial squared 0,989. Handrianto (2013), mengatakan bahwa penggunaan gadget memiliki dampak positif dan juga negatif. Dampak positif penggunaan gadget berkaitan dengan berkembangnya imajinasi yang 
melatih daya pikir tanpa dibatasi oleh kenyataan dan melatih kecerdasan dalam membantu melatih proses belajar. Menurut Gardner (2011) bahwa kemampuan berpikir erat kaitannya dengan kecerdasan. Kecerdasan seseorang tidak diukur dari hasil tes saja, namun dapat dilihat dari kebiasaan seseorang terhadap dua hal, yaitu kebiasaan seseorang menyelesaikan masalah (problem solving) dan kebiasaan seseorang menciptakan produkproduk baru (creativity). Dengan demikian kebiasaan mahasiswa memanfaatkan gadget berkaitan erat dengan cara berpikir menyelesaikan masalah dan tugas yang diberikan dosen selama proses perkuliahan (Rijal. M, 2018). Hal ini didukung oleh penjelasan Mukti Amini (2016).

Adanya ketrampilan menggunakan gadget akan melatih fungsi otak. Pemanfaatan gadget dapat melatih kecerdasan otak, kerena kemampuan menggunakan gadget dengan banyak aplikasi akan melatih koordinasi secara motoric antara indara mata dan tangan, selain itu adanya kordinasi antara pengetahuan dan perilaku. Keuntungan model pembelajaran gadget yakni terjadi kerjasama, interaksi, komunikasi diantara sesama mahasiswa di dalam kelompok maupun di luar kelompoknya dalam menyelesaikan tugastugas seperti penyusunan makalah, mencari keberadaan hewan yang akan dipraktet pada laboratorium. Kemampuan menyelesaikan tugas dari hasil unjuk kerja dalam bentuk pembedahan hewan vertebrata tidak terlepas dari penerapan model pembelajaran gadget pada perkuliahan zoology vertebrata. Kecerdasan menggunakan gadget akan sangat membantu kecerdasan unjuk kerja (psikomotorik), karena mahasiswa mampu mengekses secara online cara membedah hewan vertebrata, serta materi zoology vetebrata salin itu mereka mempu membuat laporan ilmiah berdasarkan data yang dikumpulkan selama melakukan praktikum dilaboratorium.

Berdasarkan hasil penilaian dan analisis terkait dengan kemampuan menggunakan gadget menunjukan danya pengaruh kecerdasan menggunakan gadget terhadap


$\mathrm{F}$ hitung adalah 0,000 dan nilai koefesien 0,951 > nilai partial squared 0,942. Selan itu juga adanya pengaruh penerapan model pembelajaran gadget terhadap unjuk kerja


dan nilai koefesien 0,962 > nilai partial squared 0,955. Dalilah, (2018) bahwa dampak posistif gadget dapat meningkatkan percaya diri dalam berkomunikasi, serta memiliki ketrampilan dalam menyelesaikan tudag, menambah pengetahuan Karena mudah mengakses atau mencari situssitus tentang pengetahuan dengan mengaplikasikan gadget, memberi pengaruh pada kraktivitas mahasiswa, mempermudah melaksanakan tugas-tugas yang diembankan kepada siswa atau mahasiswa. Dengan demikian mahasiswa yang memiliki ketramilan menyelesaikan tugas, serta melalukan unjuk kerja selama praktikum berlangsung dengan kriteri baik serta cepat memahami materi dan trampil menggunkan gadget atau dapat mengembangkan pengetahuannya dengan cepat melalui keterampilan memanfaatkan gadget termasuk komputer yang diperlukan, dengan mengakses Web. Oleh karena itu model pembelajar 
gadget dapat mencapai diyakini dapat mencapai standar kompetensi dan kompetensi dasar yang dirancang dalam pelaksanaan matakuliah zoology vertebrata oleh dosen.

Salah satu tuntutan yang harus dipenuhi pada penerapan model pembelajaran gadget selama proses perkuliahan adalah kemampuan mengoprasionalkan gadget bagi setiap mahasiswa selama mengikuti proses perkuliahan zoology vertebrata, sehingga melalui kemampuan oprasional gadget dapat menguasai ilmu pengetahuan dan tekonolgi yang saat ini berkembang sangat pesat. Hal ini secaran dengan pemikiran Luthvitasari, Putra, Linuwih, (2012) bahwa keberhasilan atau kesuksesan dan profesionalitas seseorang juga sangat dipengaruhi oleh kecerdasan menguasai pembelajaran E.Learning, salah satunya adalah kecerdasan mengoprasionalkan gadget yang dimilikinya. Frijters, Dam, \& Rijlaarsdam, (2008), menyatakan bahwa jika seseorang memiliki kemampuan menggunakan digital maka orang tersebut dapat bersaing secara global dan orang tersebut juga dapat ikut berperan sebagai konsumen sains.

Penerapan model pembelajaran gadget, khususnya kualitas oprasional gadget terhadap berbagai program dalam mengekses berbagai konsep-konsep vertebrata selama proses perkuliahan zoology vertebrata. Kemampuan oprasional gadget oleh mahasiswa berpengaruh terhadap sikap mereka, terutama sikap, jujur, menerima pandangan teman serta rajin dalam melakukan pertemuan kelompok bahkan diskusi menyelesaikan permasalahan atau tugas, sikap mahasiswa ini memiliki kualifikasi baik dan sangat baik lebih dominan dari pada sikap dengan keriteria cukup bahkan sikap negatif selamam proses perkuliahan berlangsung melalui model pembelajaran gadget yang dilaksanakan. Hal ini terbukti dari hasil analisis memperlihatkan adanya pengaruh model pembelajaran

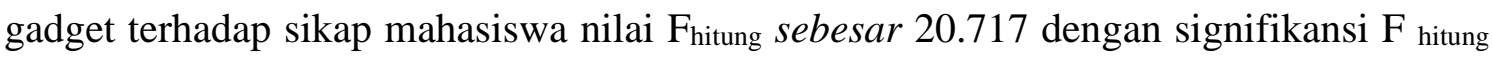
adalah 0,000 dan nilai koefesien 0,862 > nilai Partial squared 0,853. Dampak positif yang ditimbulkan akibat penggunaan gadget berupa perubahan perilaku, gaya hidup khususnya untuk mahasiswa terjadi interaksi dan komunikasi di dalam kelompok mereka serta menimbulkan ketertarikan mahasiswa pada perkuliahan dengan model gadget. Mahasiswa akan rajin belajar serta tekun dan cepat memahami materi yang dipelajari serta trampil menggunakan gadget termasuk komputer dalam mengakses Web. Kecerdasan menggunakan gadget sangat membantu berpikir kritis mahasiswa dalam mengakses konsep zoology vertebrata melalui situs E-learning yang disediakan dosen, mereka adopsi untuk meningkatkan kualitas belajar sehingga mereka lebih memahami dan menguasai meteri zoology vertebrata.

Melalui model pembelajaran gadget mahasiswa dapat mengakses berbagai situssitus pembelajaran yang terkait dengan materi perkuliahan, bahkan memudahkan mahasiswa mempelajari secara langsung melalui E-learning. Selain itu keberadaan gadget menumbuhkan sikap posistif mahasiswa, terutama rajin belajar, berdiskusi dan sering materi yang mereka akses, sikap seperti ini sangat membantu meningkatkan hasl belajar mereka. Hal ini sesuai dengan hasil analisis variance yang menunjukan ada pengaruh model pembelajaran gadget terhadap hasil belajar konsep vertebrata selama proses 
perkuliahan sesuai dengan hasil analisis variance dengan nilai $F_{\text {hitung }}$ sebesar 4.613 dengan signifikansi $\mathrm{F}$ hitung adalah 0,073 dan nilai koefesien 0,976 > nilai partial squared 0,970. Maya Ferdiana dkk, (2015) menjelaskan ada hubungan intesitas pemanfaatan gadget dengan prestasi belajar siswa, semakin tinggi intensitas penggunaan gadget semakin rendah prestasi belajar. Hal ini disebabkan mereka merupakan siswa usia dini dan lebih banyak memanfaatkan gadget sebagai media hiburan dan belum memikirkan apa itu prestasi belajar. Hal ini sejalan dengan pandngan Moeliono, (2009) banyak siswa bermain gadget mengakibatkan prestasi belajar menurun. Berbeda dengan mahasiswa yang pemanfaatan gadget sebagai sarana belajar, serana komunikasi dan sarana penyelesaian masalah.

\section{KESIMPULAN}

1. Ada pengaruh model pembelajaran gadget terhadap berpikir kritis mahasiswa selama proses perkuliahan mata kuliah zoologi vertebrata

2. Ada pengaruh model gadget terhadap penyelesaian tugas-tugas (makalah) selama proses perkuliahan mata kuliah zoologi vertebrata berlangsung

3. Ada Pengaruh model pembelajaran gadget terhadap unjuk kerja pembedahan hewan vertebrata (psikomotor) selama proses perkuliahan mata kuliah zoology vertebrata berlangsung

4. Ada pengaruh model pembelajaran gadget terhadap sikap mahasiswa selama proses perkuliahan berlangsung.

5. Ada pengaruh model pembelajaran gadget terhadap hasil belajar konsep vertebrata selama proses perkuliahan berlangsung.

\section{DAFTAR PUSTAKA}

Kashiani. K.E. Suyanto, (2008) Model Pembelajaran. Universitas Negeri Malang. Panitia Sertifikasi Guru Rayon 15. Jawa Timur

Kuroyuki. (2013). Teknologi dalam Pendidikan: Peranan Gadget untuk Pendidikan. [Online]. Tersedia: http://kuroyuki97.blogspot.co.id/2013/11/teknologi-dalampendidikan peranan.html. [4 Maret 2016].

Mulyasa E. (2007). Menjadi Guru Profesional Menciptakan Pembelajaran Kreatif dan Menyenangkan. PT Remaja Rosdakarya. Bandung

Mujib, M. (2013). Pengaruh Penggunaan Internet Terhadap Hasil Belajar Siswa Sekolah Menengah Atas Di Kota Yogyakarta. Universitas Islam Negeri Sunan Kalijaga. Yogyakarta

Munir. (2017) Pembelajaran Digital. Penerbit Alfabeta. Bandung.

Nana Sudjana. (1989) Dasar-Dasar Dalam Proses Belajar Mengajar. Sinar Baru. Bandung 
Najmi Firdaus. (2016) Keanekaragaman Vertebrata. All right reserved. Hak cipta dilindungi Undang-Undang. Dilarang memperbanyak sebagian atau seluruh isi buku ini tanpa izin tertulis dan penulis/penerbit. Cetakan Pertama:

Nelson, J.S. (2006). Fishes of the world. th4 edition. John Wiley \& Sons, Inc. New Jersey.

Putri Rachmawati, Amram Rede, Mohammad Jamhari. (2013). Pengaruh Penggunaan Gadget Terhadap Hasil Belajar Mahasiswa Pendidikan Biologi Angkatan 2013 FKIP UNTAD Pada mata kuliah Desain Media Pembelajarane. JIP BIOL Vol.5 (1): 35-40, Juni 2017. ISSN 2338-179

Rijal, M. (2018). PENERAPAN MODEL PEMBELAJARAN KOOPERATIF TIPE NUMBERED HEADS TOGETHER DALAM MENINGKATKAN AKTIVITAS DAN HASIL BELAJAR COGNITIF SISWA KELAS VIII DI SMP NEGERI 14 AMBON. Jurnal BIOEDUIN: Program Studi Pendidikan Biologi, 8(2), 6-16.

Slameto. (1995). Belajar dan Faktor-faktor Yang Mempengaruhinya. PT Rineka Cipta. Jakarta

Slameto. (2010). Belajar Dan Faktor-faktor Yang Mempengaruhi. Rineka Cipta. Jakarta Syaiful Bahri Djamarah. (1994). Prestasi Belajar Dan Kompetensi guru. Usaha Nasional. Surabaya

Sanjaya, Wina. (2006). Strategi Pembelajaran berorientasi standar proses pendidikan. Kencana Prenada Media Group. Jakarta

Saida Ulfa, (2016). Pemanfaatan Teknologi Pergerakan Sebagai Media Pembelajaran Bagi Anak Usia ini. Universitas Negeri Malang. Edcomtech Volume 1. No 1. saidaulfa@gmail.com

Simpson, G.G. (1990). Pinciples of Animal Taxonomy. Columbia University Press. New York

Wenno, I. H, (2008). Strategi Belajar Mengajar Sains Berbasis Kontekstual. Grafik Indah. Yogyakarta

Winarno, W. (2009). Panduan Penggunaan Gadget. Rineka Cipta. Jakarta 